
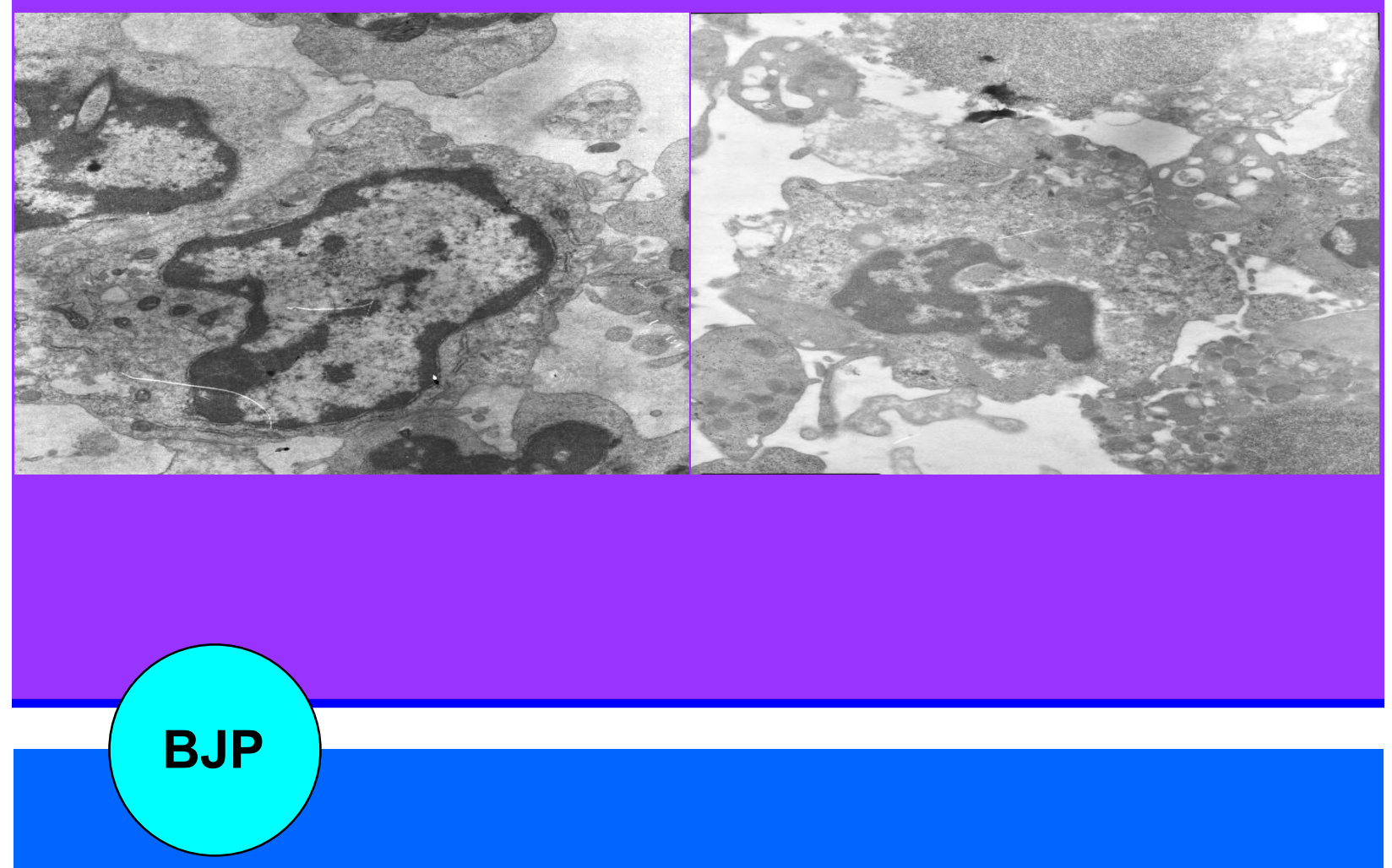

Bangladesh Journal of Pharmacology

Research Article

Effect of antisense oligodeoxynucleotide targeting survivin on growth of human gastric cancer cells 


\section{Effect of antisense oligodeoxynucleotide targeting survivin on growth of human gastric cancer cells}

\section{Lantao Xu}

Department of Gastroenterology, Fengxian District Central Hospital, Shanghai 201400, China.

\begin{tabular}{|c|c|}
\hline \multicolumn{2}{|l|}{ Article Info } \\
\hline Received: & 16 January 2013 \\
\hline Accepted: & 18 January 2013 \\
\hline Available Online: & 28 January 2013 \\
\hline \multicolumn{2}{|c|}{ DOI: 10.3329/bjp.v8i1.13337 } \\
\hline \multicolumn{2}{|c|}{$\begin{array}{l}\text { Cite this article: } \\
\text { Xu L. Effect of antisense oligodeox- } \\
\text { ynucleotide targeting survivin on } \\
\text { growth of human gastric cancer cells. } \\
\text { Bangladesh J Pharmacol. 2013; 8: 73- } \\
\text { 77.p }\end{array}$} \\
\hline
\end{tabular}

\begin{abstract}
Our study investigated the effects of antisense oligodeoxynucleotide targeting survivin on human gastric cancer cells. Human gastric cancer cells were incubated with antisense oligodeoxynucleotide targeting survivin for predesigned durations, and then the cell growth was observed under light and electronic microscopes. Electrophoresis of fractured DNA fragments was performed to detect the DNA distribution and telomere repeat amplification protocol (TRAP) was used for the detection of telomerase activity. Antisense oligodeoxynucleotide targeting survivin could induce the apoptosis of human gastric cancer cells which were characterized by plasma membrane blistering, chromatin condensation, nuclear fragmentation, and formation of apoptotic bodies. Electrophoresis showed characteristic DNA ladder. Flow cytometry revealed hypo-diploid apoptosis peak before G1 phase and the telomerase activity was significantly inhibited. These results demonstrated antisense oligodeoxynucleotide targeting survivin can induce the apoptosis of gastric cancer cells to inhibit their proliferation.
\end{abstract}

\section{Introduction}

Although studies have confirmed that the occurrence and development of cancers have the involvement of a complex cancer-related gene network, the changes in the functions of these genes share the consequence that cells develop uncontrolled proliferation and disruption of apoptosis. Survivin is a new member of inhibitor of apoptosis protein (IAP), has high expression in cancers and can exert anti-apoptotic effect (Ambrosini et al., 1997; Mesri et al., 2010). Survivin is a newly identified anti-apoptotic molecule and its over-expression is frequently observed in cancers. Thus, the development and application of survivin signaling pathway are beneficial for the early diagnosis of cancers and the determination of prognosis of cancer patients and also provide new targets for the biotherapy of cancers. Antisense oligonucleotide targeting survivin (ASODN) can induce the apoptosis of hepatic cancer cells and inhibit their growth (Grossman et al., 2006; Altieri and Marchi- sio, 2006; Tanabe et al., 2006). In the present study, survivin ASODN was transfected into human gastric cancer cells and the anti-tumor effects were then observed. Our findings may provide theoretical and experimental bases for the treatment of gastric cancer.

\section{Materials and Methods}

\section{Reagent and cell lines}

RPMI 1640 (GIBCO, USA), Annexin V FITC/PI (Jingmei, China), protease K (Roche, Swiss), acridine orange, ethidium bromide (Sigma, USA), Bcl-2 immunohistochemical detection kit (Boster, China), survivin ASODN and unrelated oligonucleotide (N-ODN) (Full phosphorothioate; Shanghai Sangong, China), MTT and SDS (Shanghai Sangong, China) were used in the present study. The sequence of ASODN was 5'CCCAGCCTTCCAGCTCC TTG-3'and that of N-ODN 
was 5'-GCCACTCCTCGAC TCTCGTG-3'. Both sequences have no homology with corresponding genes of humans.

Human gastric cancer cell line (SGC-7901) was purchased from the Cell Bank of Shanghai Institute of Cell Biology in Chinese Academy of Science. Cells in the logarithmic growth phase were used in the experiments. In the ASODN groups, cells were treated with ASODN at different concentrations $\left(1 \times 10^{-5} \mathrm{~mol} / \mathrm{L}, 2 \times\right.$ $10^{-5} \mathrm{~mol} / \mathrm{L}, 3 \times 10^{-5} \mathrm{~mol} / \mathrm{L}, 4 \times 10^{-5} \mathrm{~mol} / \mathrm{L}$ and $5 \times 10^{-5}$ $\mathrm{mol} / \mathrm{L}$ ), and cells were incubated with $\mathrm{N}-\mathrm{ODN}$ in the $\mathrm{N}$ -ODN group. In the control group, cells were treated with normal saline. Incubation was performed at $37^{\circ} \mathrm{C}$ in an environment with $5 \% \mathrm{CO}_{2}$.

\section{Effect of ASODN on growth of SGC-7901 cells}

SGC-7901 cells were seeded into 96-well plates at a density of $2 \times 10^{7} /(100 \mu \mathrm{L} /$ well $)$, and three wells in each group. The final concentrations of ASODN were $1 \times 10^{-5}$ $\mathrm{mol} / \mathrm{L}, 2 \times 10^{-5} \mathrm{~mol} / \mathrm{L}, 3 \times 10^{-5} \mathrm{~mol} / \mathrm{L}, 4 \times 10^{-5} \mathrm{~mol} / \mathrm{L}$ and $5 \times 10^{-5} \mathrm{~mol} / \mathrm{L}$, and that of N-ODN was $5 \times 10^{-5}$ $\mathrm{mol} / \mathrm{L}$. Incubation was done for $24,48,72$ and 96 hours. At 4 hours before the detection, $5 \mathrm{~g} / \mathrm{L}$ MMT $(20 \mu \mathrm{L})$ was added to each well followed by incubation for 4 hours. SDS $(100 \mu \mathrm{L})$ was added to stop the reaction. After incubation overnight at $37^{\circ} \mathrm{C}$, the absorbance (D) was measured at $570 \mathrm{~nm}$ with a microplate reader.

\section{Morphology of SGC-7901 cells before and after ASODN treatment}

During the treatment with ASODN, the cell growth and morphology were observed under an inverted microscope. In addition, cells which were treatment with ASODN for 3 days were collected, and the morphology of apoptotic cells was evaluated.

\section{Detection of mRNA expression of survivin in SGC-7901 cells}

After treatment with $5 \times 10^{-5} \mathrm{~mol} / \mathrm{L}$ ASODN for 24 and 48 hours, cells were harvested and total RNA was extracted with Trizol followed by PCR. The products were subjected to $1.7 \%$ agarose gel electrophoresis, and representative photographs were captured.

\section{DNA extraction and electrophoresis}

Cells at $1 \times 10^{9} / \mathrm{L}$ were treated with $5 \times 10^{-5} \mathrm{~mol} / \mathrm{L}$ ASODN for 3 days and then washed with buffer by centrifugation. These cells were fixed in ethanol. After addition of lysis buffer and protease $\mathrm{K}$, the cells were incubation at $37^{\circ} \mathrm{C}$ for 2 hours. Extraction of DNA was done with phenol, chloroform and isoamyl alcohol sequentially. The $1 / 10$ volume of $3 \mathrm{~mol} / \mathrm{L}$ sodium acetate and 2 volume of cold ethanol were added to the supernatant followed by incubation at $-20^{\circ} \mathrm{C}$ overnight. Then, centrifugation was performed at $-10^{\circ} \mathrm{C}$ for $10 \mathrm{~min}$ at $800 \times \mathrm{g}$ and the sediment was collected. After addition of TE buffer, $5 \mu \mathrm{L}$ of DNA was subjected to $20 \mathrm{~g} / \mathrm{L}$ agarose gel electrophoresis at $50 \mathrm{~V}$ for 3 hours. Bands were observed under a UV lamp, and representative photographs were obtained.

Detection of apoptosis of SGC-7901 after ASODN treatment by flow cytometry

Gastric cancer cells at $1 \times 10^{9} / \mathrm{L}$ were treated with $5 \times$ $10^{-5} \mathrm{~mol} / \mathrm{L}$ ASODN for 3 days and then washed in buffer twice. These cells were fixed in absolute ethanol for 24 hours followed by washing. After incubation with Tris- $\mathrm{HCl}$ buffer $(\mathrm{pH}=7.4)$ containing $10 \mathrm{~g} / \mathrm{L}$ RNAase for $10 \mathrm{~min}$, cells underwent DNA staining with propidium iodide and then subjected to flow cytometry.

\section{Electric microscopy}

Gastric cancer cells at $1 \times 10^{9} / \mathrm{L}$ were incubated with 5 $\times 10^{-5} \mathrm{~mol} / \mathrm{L}$ ASODN for 3 hours and then washed in PBS twice. These cells were fixed in $2.5 \%$ glutaraldehyde for 24 hours and then washed in $0.2 \mathrm{~mol} / \mathrm{L}$ PBS thrice (15 min for each). Cells were subsequently fixed in $1 \%$ osmic acid for 1 hours followed by washing. After dehydration in acetone, cells were embedded in Epon 812, and ultrathin sections were obtained with the LKP-2088 microtome. Following staining with uranyl acetate-citrate aluminum, cells were observed under a transmission electron microscope, and representative photographs were captured.

\section{Effect of survivin ASODN on activity of telomerase in SGC-7901 cells}

Gastric cancer cells at $1 \times 10^{9} / \mathrm{L}$ were treated with $5 \times$ $10^{-5} \mathrm{~mol} / \mathrm{L}$ ASODN for 3 days and washed with buffer once. After centrifugation at $4^{\circ} \mathrm{C}$ for $1 \mathrm{~min}$ at $800 \times \mathrm{g}$, the sediment washed with $150 \mu \mathrm{L}$ of washing buffer by centrifugation for $1 \mathrm{~min}$. The sediment was re-suspended in $50 \mu \mathrm{L}$ of lysis buffer, and this solution was then kept on ice for $30 \mathrm{~min}$. After centrifugation at $4^{\circ} \mathrm{C}$ for 20 min at $1000 \times \mathrm{g}$, the supernatant $(2 \mu \mathrm{L})$ was used as the template in TRAP. Then, $45 \mu \mathrm{L}$ of reaction mixture and $2 \mu \mathrm{L}$ of processed sample were mixed in a reaction tube. After addition of $30 \mu \mathrm{L}$ of liquid paraffin, the solution was incubated at $25^{\circ} \mathrm{C}$ for $30 \mathrm{~min}$. PCR was performed as follows: $94^{\circ} \mathrm{C}$ for $120 \mathrm{sec}, 94^{\circ} \mathrm{C}$ for $30 \mathrm{sec}, 48^{\circ} \mathrm{C}$ for 30 sec, $72^{\circ} \mathrm{C}$ for $90 \mathrm{sec}$ and $72^{\circ} \mathrm{C}$ for $300 \mathrm{sec}$. A total of 35 cycles of PCR were done. Then, hybridization solution and $25 \mu \mathrm{L}$ of products from PCR were added to each well followed by incubation at $37^{\circ} \mathrm{C}$ for $60 \mathrm{~min}$. Negative control and blank control were also included. After addition of chromogenic agent, incubation was done at $37^{\circ} \mathrm{C}$ in dark for $10 \mathrm{~min}$. Then, stop solution was added to stop the reaction, and the absorbance was measured at $450 \mathrm{~nm}$.

\section{Statistical analysis}

Data were expressed as mean $\pm \mathrm{SD}$, and comparisons were done with analysis of variance. A value of $p<0.05$ was considered statistically significant. 


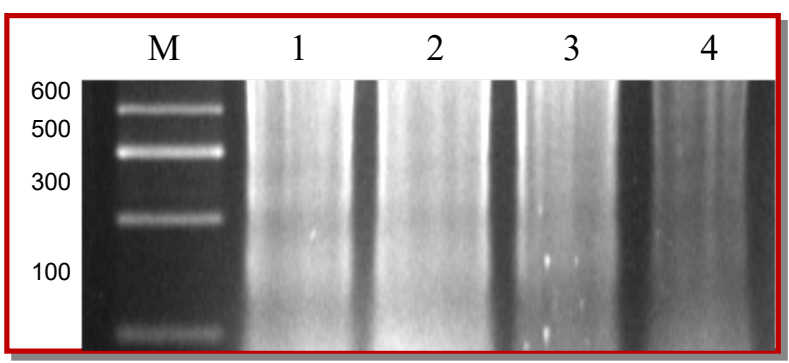

Figure 1: Survivin mRNA expression in gastric cancer cells. 1: $\mathrm{N}$ -ODN group; 2: Control group; 3: ASODN group [24 hours]; 4: ASODN group [48 hours]; M: Marker

\section{Results}

Results showed cells in the N-ODN group and control group were positive for mRNA expression of survivin. However, after ASODN treatment for 24 and 48 hours, the mRNA expression of survivin was markedly inhibited (Figure 1).

After treatment with ASODN at different concentrations, the cell growth was inhibited to different extents, which was in a time and concentration dependent manner. In the N-ODN group, the growth of gastric cancer cells remained unchanged (Table I).

Under invert microscope, cells in the N-ODN group and control group were epithelium-like and presented with adherent growth. These cells had clear borderline, closely arranged cellular structure and active growth. In the ASODN group, cells became round and suspended, the intercellular space increased, the cell growth reduced, and the cellular granules also increased. With the increase in ASODN concentration, the cellular debris increased. After treatment with $5 \times 10^{-5} \mathrm{~mol} / \mathrm{L}$ ASODN for 3 days, cells were observed under an invert microscope. The nucleus was dark-stained and crescent, and aggregated besides the nuclear membrane. The membrane protruded in a blister-like manner. The shedding of these blisters formed apoptotic bodies containing nucleosome fragments. In the N-ODN group and control group, the cell morphology remained unchanged (Figure 2) .

Under electric microscope, the SGC-7901 cells presented with chromatin condensation, and chromatins mainly aggregated besides the nuclear membrane in a blocklike or crescent manner. Condensation of cytoplasm and cellular debris were observed, accompanied by a lot of apoptotic bodies with different sizes. Under a transmission electric microscope, the electron density of cytoplasm and nucleus increased in cells undergoing ASODN treatment, and the cell volume reduced. The cell membrane shrunk or curled to form bud protrusions (budding). In addition, the cytoplasm condensed, the density of cytoplasm and organelles increased, and the organelles were oppressed. The nuclear chromatins became pyknotic and dense, and aggregated besides the nuclear membrane (chromatin margination). The nucleus was also pyknotic and became smaller. In the control group, the cell volume was relatively large, the nuclear and cell membranes were integrate, the chromatins were light, organelles arranged in a loose manner, and the nucleus was large and had normal structure (Figure 3).

In apoptotic cells, the endogenous endonucleases were activated, and DNA was cut at the junction between nucleosomes forming 180-200 bp oligonucleotide fragments. Agarose gel electrophoresis showed the typical DNA ladder. After treatment with $5 \times 10^{-5} \mathrm{~mol} /$ L ASODN, agarose gel electrophoresis and ethidium bromide staining showed obvious DNA ladder which was absent in the control group.

Flow cytometry showed the apoptotic peak of hypodiploid before G1 phase in cells treated with $5 \times 10$ $-5 \mathrm{~mol} / \mathrm{L}$ ASODN for 3 days. In the control group, apoptotic peak was absent. (Figure 4). After ASODN treatment, the apoptosis rate was $25.0 \pm 0.5 \%$ which was markedly higher than that in the control group $(7.0 \pm$ $0.2 \% ; \mathrm{p}<0.01)$. Moreover, the apoptosis rate increased over the increase in ASODN concentration, and the ASODN concentration was positively related to the apoptosis rate $(\mathrm{r}=0.820$; Table II).

Gastric cancer cells were treated with $5 \times 10^{-5} \mathrm{~mol} / \mathrm{L}$

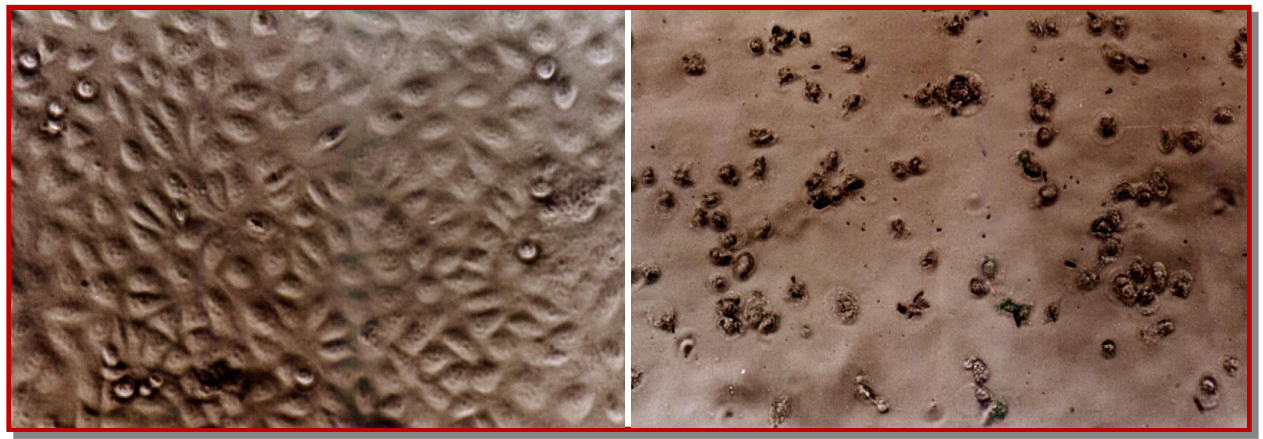

Figure 2: Morphology of cells in different groups under light microscope $(\sim 100 \times)$. (A) Control group; (B) ASODN group $\left(5 \times 10^{-5}\right.$ mol/L) 


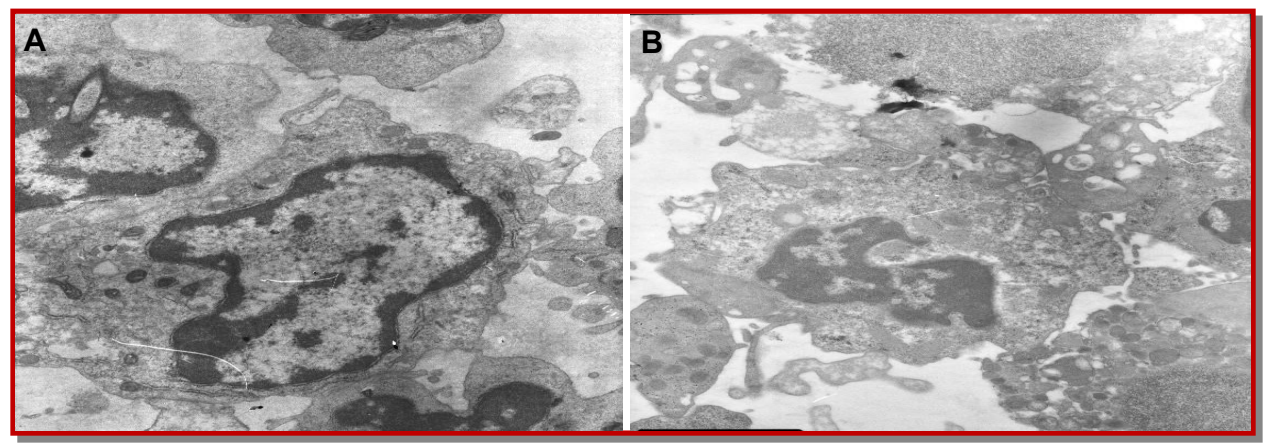

Figure 3: Morphology of SGC-7901 cells in different groups under transmission electric microscope. (A) Control; (B) ASODN group

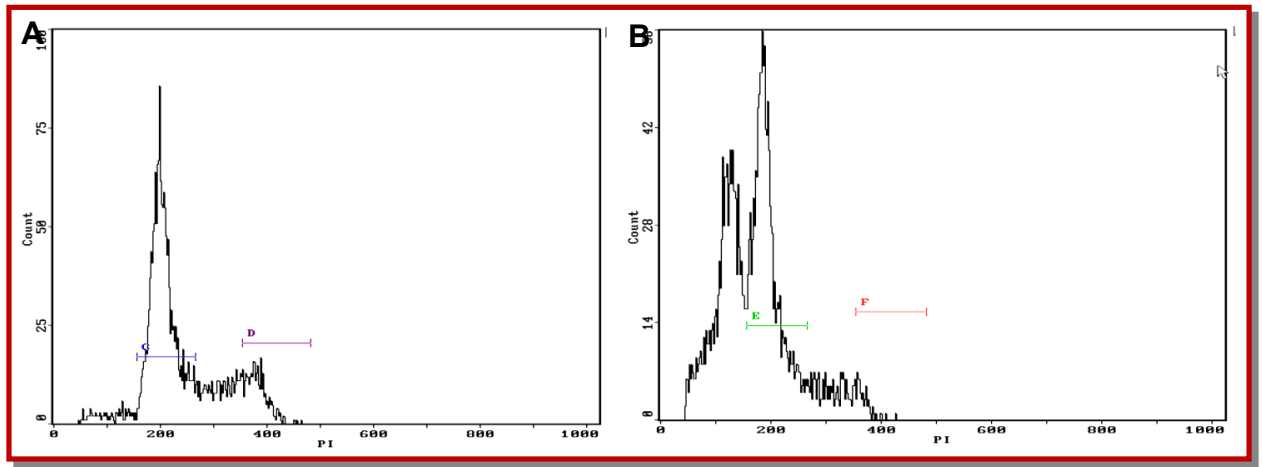

Figure 4: Detection of apoptotic cells by flow cytometry. An apoptotic peak was found before G1 phase. (A) control; (B) ASODN group

ASODN for 3 days, and results showed the telomerase activity was significantly inhibited. The absorbance in the ASODN group, control group and N-ODN group was $0.007,0.15$ and 0.14 , respectively, showing marked difference between ASODN group and control group/ N-ODN group. This suggests that ASODN can significantly inhibit the activity of telomerase in SGC7901 cells $(\mathrm{p}<0.01)$.

\section{Discussion}

To induce the apoptosis of cancer cells has been a strategy in the treatment of cancers. The survivin has specific anti-apoptotic effect and is highly expressed in cancers. Thus, survivin has been a target in the treatment of cancers. The activation of caspase cascade is a major mechanism underlying the cell apoptosis. Survivin can directly act on caspase- 3 and -7 to block the procession of apoptosis (Nagata, 2005; Thompson, 2006; Graeber et al., 2005). Antisense technique can be used to inhibit the transcription and/or translation of target genes. In the present study, ASODN and N-ODN were used to treat gastric cancer cells. Our results showed ASODN could significantly inhibit the growth of gastric cancer cells, induce their apoptosis and inhibit their telomerase activity. Thus, survivin can be used as a target in the treatment of cancers. Our findings provide a new target for the development of anti-tumor drugs and present with a novel way for the gene therapy of cancers (Shinozawa et al., 2005; Tsuji et al., 2011; Chang et al., 2009; Miao et al., 2010; Tarnawski et al., 2005; Idenoue et al., 2011).

Cell apoptosis has specific morphological and biochemical characteristics. Morphologically, apoptotic cells have small volume, cytoplasm is pyknotic or has blisters, nucleus is pyknotic and apoptotic bodies can be observed. Molecularly, apoptotic cells present with degradation of DNA in the nucleus, which is attributed to the $\mathrm{Ca}^{2+}$ and $\mathrm{Mg}^{2+}$ dependent activation of endonucleases. After leavage by endonucleases, DNA is fragmented. The shortest DNA fragment is 180-200 bp in

Table II

\section{Apoptosis rate of gastric cancer cells in different} groups

\begin{tabular}{|lc|}
\hline Group & Apoptosis rate (\%) \\
\hline Control & $7.0 \pm 0.2$ \\
Lipofectin & $7.0 \pm 0.2$ \\
N-ODN & $6.9 \pm 0.2$ \\
ASODN $\left(1 \times 10^{-5} \mathrm{~mol} / \mathrm{L}\right)$ & $10.4 \pm 0.4$ \\
ASODN $\left(3 \times 10^{-5} \mathrm{~mol} / \mathrm{L}\right)$ & $19.4 \pm 0.5^{\mathrm{a}}$ \\
ASODN $\left(5 \times 10^{-5} \mathrm{~mol} / \mathrm{L}\right)$ & $25.0 \pm 0.5^{\mathrm{a}}$ \\
${ }^{a}<<0.01$ vs control group & \\
\hline
\end{tabular}


length, and the remaining DNA fragment is multiples of 180-200 bp in length (oligomer). Agarose gel electrophoresis can reveal characteristic DNA ladder. In the apoptotic cells, the cellular DNA is degraded, and flow cytometry can present with apoptotic peak of hypodiploid. In the present study, our results showed ASODN could induce the apoptosis of gastric cancer cells. The development and use of survivin signaling pathway are beneficial for the early diagnosis of cancers and the determination of prognosis of cancer patients. Our findings provide a new target for the biotherapy of cancers.

This study shows that ASODN can induce the apoptosis of gastric cancer cells to inhibit their growth and suppress their telomerase activity. This suggests that antisense oligodeoxynucleotide targeting survivin can effective inhibit the growth of cancer cells, which provide experimental basis for the gene therapy of cancers targeting survivin. In a majority of normal cells, the telomerase is inactivated. Thus, therapy targeting survivin may avoid the activation of telomerase, which reduce the side effects and increase the therapeutic specificity.

\section{References}

Altieri DC, Marchisio PC. Survivin apoptosis: An interloper between cell death and cell proliferation in cancer. Lab Invest. 2006; 79: 1327-33.

Ambrosini G, Adida C, Altieri DC. A novel anti-apoptosis gene, survivin, expressed in cancer and lymphoma. Nat Med. 1997; 3: 917-21.

Chang JT, Wong FH, Liao CT. Enzyme immunoassay for serum autoantibody to surviving and its findings in headand-neck cancer patients. Clin Chem. 2009; 11: 1261-64.
Graeber TG, Osmanian C, Jacks T. Hypoxia-mediated selection of cells with dimished apoptotic in solid tumours. Nature 2005; 379: 88-91.

Grossman D, Kim PJ, Blanc-Brude OP. Transgenic expression of survivin in keratinocytes counteracts UVB-induced apoptosis and cooperates with loss of P53. J Clin Invest. 2006; 108: 991-99.

Idenoue S, Hirohashi Y, Torigoe T, Sato Y, Tamura Y, Hariu H, Yamamoto M, Kurotaki T, Tsuruma T, Asanuma H, Kanaseki T, Ikeda H, Kashiwagi K, Okazaki M, Sasaki K, Sato T, Ohmura T, Hata F, Yamaguchi K, Hirata K, Sato N. A potent immunogenic general cancer vaccine that targets survivin, an inhibitor of apoptosis proteins. Clin Cancer Res. 2011; 11: 1474-82.

Mesri M, Wall NR, Li J. Cancer gene therapy using a surviving mutant adenovirus. J Clin Invest. 2010; 108: 981-90.

Miao GY, Lu QM, Zhang XL. Downregulation of survivin by RNAi inhibits growth of human gastric carcinoma cells. World J Gastroenterol. 2010; 13: 1170-74.

Nagata S. Aoptosis by death factor. Cell 2005; 88: 355-65.

Shinozawa I, Inokuchi K, Wakabayashi I. Disturbed expression of the anti-apoptosis gene,Survivin,and EPR-1 in hematological malignancies. Leuk Res. 2005; 24: 965-70.

Tanabe H, Yagihashi A, Tsuji N. Expression of survivin mRNA and livin mRNA in non-small-cell lung cancer. Lung Cancer. 2006; 46: 299-304.

Tarnawski A, Pai R, Chiou SK, Chai J, Chu EC. Rebamipide inhibits gastric cancer growth by targeting survivin and Aurora-B. Biochem Biophys Res Commun. 2005; 334: 207-12.

Thompson CB. Apoptosis in the pathogenesis and treatment of disease. Science 2006; 267: 1456-62.

Tsuji N, Furuse K, Asanuma F. Mutations of the p53 gene and loss of heterozygosity at chromosome $17 \mathrm{p} 13.1$ are associated with increased Survivin expression in breast cancer. Breast Cancer Res Treat. 2011; 87: 23-31.

Author Info
Lantao Xu (Principal contact)
e-mail: xulantao@yeah.net 